\title{
"PERIMETERS OF GRIEF": ELEGY IN AND OUT OF BOUNDS IN FRED D'AGUIAR'S \\ MEMORIAL POETRY
}

\author{
"PERIMETERS OF GRIEF": LOS LÍMITES \\ DE LA ELEGÍA EN LA POESÍA MEMORIAL \\ DE FRED D'AGUIAR
}

\section{LOURDES LÓPEZ-ROPERO}

Universidad de Alicante

lourdes.lopez@ua.es

\begin{abstract}
While Fred D'Aguiar's preoccupation with acknowledging the dead and honoring their memory gives his work an idiosyncratic elegiac quality, it is with the publication of the poetic sequence "Elegies", from the collection Continental Shelf(2009), that the author overtly pitches himself in the traditional terrain of the elegy as a poetic genre. This sequence, a response to the Virginia Tech shootings (April 16, 2007), the deadliest gun rampage in US history to date, invites critical attention not only because it remains critically unexamined, but also because through its title it presents itself as an elegy when an anti-elegiac turn has been identified in modern poetry. This paper will explore D'Aguiar's intervention in the debate surrounding elegy's contemporary function as a genre which oscillates between the poles of melancholia and consolation, thus contributing to shaping the contours of an ancient but conflicted poetic form for the $21^{\text {st }}$ century. I will be arguing that D'Aguiar's poem suggests that for elegy to serve the troubled present it may benefit from the cultivation of an unembarrassed attachment to the deceased, from avoiding depoliticizing tragedy and from the exposure of its socio-historical underpinnings. In sum, it should be open to engaging with such critical issues as the struggles of collective memory, or the turning of grief into mass-mediated spectacle.
\end{abstract}

Keywords: mass death, school shootings, anti-elegy, sonnet, memory. 


\section{Resumen}

Si bien la preocupación de Fred D'Aguiar por el reconocimiento y memoria de las víctimas de la historia le otorga a su trabajo un idiosincrático carácter elegíaco, es en su publicación de la secuencia poética "Elegies", de la colección Continental Shelf (2009), donde el autor se sitúa en el tradicional terreno de la elegía como género poético. Esta secuencia, una respuesta a la masacre de Virginia Tech, el tiroteo más letal de la historia de los Estados Unidos, invita un análisis crítico no sólo porque no ha sido objeto de estudio sino también porque, a través de su título, se presenta al lector como una elegía, cuando un giro anti-elegíaco ha sido identificado en la poesía moderna. Este artículo pretende explorar la intervención de D'Aguiar en el debate en torno a la función contemporánea de la elegía como un género que oscila entre los polos de la melancolía y la consolación, contribuyendo así a perfilar el contorno de una forma poética antigua pero controvertida en el siglo veintiuno. Argumentaré que el poema de D'Aguiar sugiere que para que la elegía se adapte a las necesidades del presente se puede beneficiar del cultivo de un vínculo melancólico con los fallecidos, debe evitar despolitizar la tragedia e intentar exponer sus raíces socio-históricas y, en resumen, debe estar abierta a tratar temas fundamentales como los conflictos de la memoria colectiva, o la conversión del dolor en espectáculo mediático.

Palabras clave: asesinato masivo, tiroteo escolar, anti-elegía, soneto, memoria.

\section{Introduction}

A confrontation with loss and an impulse towards its memorialization is a dominant thread running through the work of US-based Guyanese author Fred D'Aguiar, from his slavery novels The Longest Memory (1994), Feeding the Ghosts (1997), and novel in verse Bloodlines (2000), to his poetic revisitation of the Jonestown massacre in Bill of Rights (1998) and in his last novel to date Children of Paradise (2014). While this preoccupation with acknowledging the dead and honoring their memory gives D'Aguiar's work an idiosyncratic elegiac quality, it is with the publication of the poetic sequence "Elegies", the centerpiece of his poetry collection Continental Shelf (2009), that he overtly pitches himself in the traditional terrain of the elegy as a poetic genre. "Elegies" is a response to the deadliest gun rampage in US history to date, the Virginia Tech shooting, in which thirty-two people, mostly students, thirty-three including the perpetrator, lost their lives at the hands of a fellow student. The tragedy took place on April 16, 2007 in Blacksburg, the main campus of Virginia Polytechnic Institute and State University, when D'Aguiar was a professor at this institution. 


\section{Elegy in and out of Bounds in Fred D'Aguiar}

As we shall see, D'Aguiar's elegy works on different levels. It is a memorial to the dead and, on a more personal level, it signals the author's attempt to address the tragedy as a grieving human being, as a teacher, as a father, as a community member, and as a diasporic intellectual who lives in the same country as the victims — "The country I'm in is the country of their birth" (2009: 58). This poetic sequence invites critical attention not only because it remains critically unexamined with the exception of some short reviews (Burns 2010; McCulloch 2020), but also because through its title it presents itself as an elegy when an anti-elegiac turn has taken place in poetry. Therefore, this paper sets out to explore D'Aguiar's recourse to this literary tradition with the aim of identifying how the author partakes in the debate surrounding elegy's contemporary function as a genre which oscillates between the poles of melancholia and consolation (Ramazani 1994, 2006; Spargo 2004, 2010; Fuss 2013), and thus contributes to shaping the contours of an ageold but conflicted poetic form for the $21^{\text {st }}$ century. In addition to evoking the theme of tragic death, the phrase "perimeter of grief", extracted from the poem (D'Aguiar 2009: 80) and serving as the cue for my title, will be used metaphorically to refer to the author's redrawing of the boundaries of the classic elegy over the course of his poetic sequence, and to his ongoing search for ways of confronting absence and circling the many ramifications of loss, including who is embraced in the circle of grief.

\section{Elegy within Bounds}

Speaking of his motivation for writing "Elegies" on the first anniversary of the tragedy, D'Aguiar seems to appeal to the conventional understanding of this genre as consolatory and therapeutic art:

$[\ldots]$ the elegiac art of poetry, when faced with grief, makes marvellous things happen. The event of the poem stages immersion in pain and catharsis from it, the drama of a hurt relived, thought and felt through. As a result I found myself writing sonnet after sonnet about April 16, about grief for the dead. (2008)

The author's journey through grief results in a long sequence of one hundred and thirty-seven poems, most of them sonnets, divided into twenty-one sections of unequal length. Part One deserves especial attention, not only because it stands alone as a self-contained section condensing the main events surrounding the tragedy and introducing key issues that will be developed in subsequent poems, but also because it roots itself in poetic tradition by emphasizing form and featuring important elegiac tropes. This section inaugurates the form that will shape the sequence and help, in the author's view, to "contain the sprawl of emotions" triggered by the tragedy (D'Aguiar 2008). The sonnet, although having a shorter history than the 
elegy, became associated with the elegy's mournful subject matter alongside the brighter theme of love, and in fact both themes intertwine in Petrarch's sonnets lamenting his frustrated love for and the premature death of Laura (Robinson 2003: 200-201). Further emphasizing the author's adherence to traditional form, the poems are slight variations of the terza rima sonnet, a poetic form consisting of four tercets and a couplet with an interlocking rhyme scheme of aba bcb cdc ded ee (Amano 2006: 40-41). While adopting this poetic formula, D'Aguiar somehow loosens the rigidity of the interlocking pattern, particularly after the second or third tercet of each sonnet, - e.g. nightmare/drive/there live/dead/eyes head/sky/hills stance/still/advance grave/Save (D'Aguiar 2009: 51). The use of terza rima is quite fitting, as this pattern, devised by Dante for The Divine Comedy, has attracted modern poets for its "association with speaking to and hearing the dead" (Lennard 2013: 41-42). In fact, D'Aguiar alludes to Dante in a later section saying that the tragedy has "left [them] in the lower echelons of Dante's hell" (2009: 96), linking the aftermath of the massacre to the idea of hell for the living.

As the section opens, we are presented with D'Aguiar on the day of the tragedy going through his morning routine as a tenure-track professor. This includes "Deleting email, returning calls", but also "watching live/ Feed of the latest from Iraq whose mounting dead-/ Their drawn, bloodless faces and wide, watery eyes/ Pleading to camera lens - fill my scabrous head" (2009: 51). The reference to the Iraq war here may be understood as an intimation of the violence to come, but coupled with other ordinary tasks, it functions more as a distant reality one has become accustomed to than as a pressing issue. The development of a certain numbness to the disasters taking place elsewhere is also suggested by the adjective "scabrous", with its meaning of something rough and scabby, and the news from Iraq does not trigger any other response or alter the professorial routine described in these early lines of the poem. The instinctive displacement of danger and insecurity to a distant location is highlighted by the way the poet expects the sound of sirens suddenly "invad[ing]" his office to "pass" (51). And yet, the realization that tragedy has struck very close to home gradually imposes itself, when over twenty lines later the sirens are described as "building a wedding cake of sound" (52), danger materializing in the language of the poem through the synesthetic conversion of sound into matter - a cake of sound. The news of the rapidly growing death toll attributed to the shooter gives way to a leaden silence. Sound, this time its absence, is once more made solid as the living, in their flight from campus to safety, are described as "scissor[ing] through" its "fabric [...] with threaded tyres" (54).

In keeping with its emphasis on form, Part One features several elegiac conventions such as the announcement and account of death, the expression of anger against 


\section{Elegy in and out of Bounds in Fred D'Aguiar}

it, the motif of life extinguished in its prime, eulogy, apostrophe, and the final apotheosis of the dead (Norlin 1911; Cannon 1963). The account of how the victims died is summed up in what seems a sudden outburst of anger in the first tercet of one of the poems: "Not twenty but thirty-two innocents killed, just think,/ Thirty-two mown down in classrooms by weapons/ You can buy legally before you can legally drink" (D'Aguiar 2009: 54). The verb "mow down" graphically conveys the familiar trope of life cut off in its prime (Norlin 1911: 296), very characteristic of elegies for the death of children or young individuals. The poet eulogizes one of the victims, a student called Erin whom he knew personally because she was in his Caribbean literature class, fearing the moment of eventual confrontation with her empty desk. He praises her competitive spirit as an athlete and her resolution to improve her grade in the next assignment the last time they spoke (D'Aguiar 2009: 55). In the final couplet of another poem, the poet apostrophizes the dead student saying "Erin, queen of the court and brightest light in the room,/ You are a bride now and death is your bridegroom" (55). Echoes of Emily Dickinson's poem "Because I could not stop for death", where death appears as a gentle suitor who takes the poet for a ride in his carriage, reverberate in the second line of the couplet, imaginatively freeing Erin from the rawness of her actual death, and perhaps softening the poet's grief.

The eulogy for one of the victims is followed by a meditation on the perpetrator of the massacre in the penultimate poem of this section. The poet, who had had a few tutorials with the shooter after he was expelled from a Poetry course, expresses feelings of guilt at not having noticed anything in him "to ring an alarm and get him treated", while also pointing at the difficulty of accessing the mind of such an inarticulate individual (D'Aguiar 2009: 56). This section closes with a recourse to a fundamental elegiac convention. As Norlin explains, while the elegy "is mainly an expression of despair, it contains also an element of reassurance and consolation in the thought that the dead is not really dead but lives on in another world" (1911: 309). A canonical example of this trope is found, for instance, in Shelley's elegy on Keats, "Adonais", which ends with the astral elevation and rebirth of the dead poet: "[...] burning through the inmost veil of Heaven,/ The soul of Adonais, like a star,/ Beacons from the abode where the Eternal are" (1821). This final resurrection or "apotheosis" often found in traditional elegies is part of a linear pattern of "transition from despair to reassurance" (Norlin 1911: 310), or "movement from grief to consolation" (Kennedy 2007: 6), which can be expressed using images taken from religion, myth or paganism (Norlin 1911: 310). Thus, after offering several natural images suggestive of the continuity of life, like the return of the sun after a storm, in D'Aguiar's poem the dead are incorporated into the natural cycle and become figuratively transmuted into a rainbow: 


\section{Lourdes López-Ropero}

$[\ldots]$ those thirty-two souls may be found in a vast

Sky shared by sun and rain and a double rainbow

With colours for each of the dead looped and unfolding

From one end of the Roanoke Valley to another. (2009: 56)

In keeping with this image of natural rebirth, in the concluding couplet the living are left "To witness that gift of rain and wealth of sun,/ We know this week is not the end but new life begun" (56). Thus, the feelings of grief, resentment, anger, guilt, and shock that pervade Part One of the elegiac sequence give way, in the final poem, to a suggestion of tranquillity, consolation, and closure.

\section{Widening Elegy's Perimeter}

It soon becomes clear after Part One, however, that the author is not fully satisfied with elegy's traditional solution to grief, as the plural in the title of D'Aguiar's poetic sequence seems to anticipate. As we will see, in the remaining parts of the sequence the poet steps out of the 'safe' perimeter of tradition, although it is true that the sonnet form is largely maintained, in the author's admission, to "help contain the sprawl of emotions linked to the thirty-three campus dead" (2008). And yet this choice of closed form shows an understanding of tradition as "a way of controlling, of ordering, of giving a shape" to a complex range of materials (Eliot 1975: 177), rather than signalling blind adherence to the scripts of the past. In fact, while the sonnet structure provides scaffolding for the whole sequence, the interlocking rhyme scheme fades away, and the use of traditional elegiac tropes is abandoned in subsequent poems. These grow not linearly, but organically like "a collage of snapshots" (McCulloch 2010:22) out of the poet's need to explore his grief, and meditate on loss and the implications of the tragedy, thus pushing the boundaries or widening the perimeters of the elegy. It is interesting to note that one reviewer has found this expansiveness objectionable: "I'm still not convinced that the sequence fully succeeds. It $[\ldots]$ tended to lessen its effect by being so long. 'Diffuse' was the word [...]. There are times when a few words can make for the best kind of elegy" (Burns 2010: 61).

Clearly, in "Elegies" D'Aguiar is not after producing a singular effect, or a sense of resolution and closure through brevity that would allow him and the reader to commemorate an absence and move forward. He provides a more immersive experience, an elegy in the making, as he explains self-reflexively in Part Seventeen saying, "In this lyric there's no such plot/ The whole story remains ever present,/ Charts an ever changing feeling" (2009: 108). Another reviewer appears to have grasped the poet's method more accurately, commenting on how "poetic form $[\ldots]$ seems either inappropriate or unequal to the task of dealing with his demons" 


\section{Elegy in and out of Bounds in Fred D'Aguiar}

(McCulloch 2010: 22). As has been argued in relation to his novel in verse Bloodlines, whose prose is inflected with ottava rima, another traditional Italian verse form, D'Aguiar adapts generic conventions in a way that suits his thematic preoccupations, and as a way to foreground the difficulty of "finding a form appropriate to his subject" (Birat 2018: 59).

In his review of Joyce's Ulysses, Eliot invites readers to view "formless[ness]" not as a flaw, but as an enlightened awareness on the part of authors of the "obsolescence" of certain literary forms at a given time (1975: 177). A similar realization struck modern practitioners of the poetic elegy, Jahan Ramazani explains, who "over the course of the twentieth century [...] have drawn upon and transformed an age-old language of mourning, alloying the profound insights of the past with the exigencies of the present" (1994: ix). The result, he adds, is "a poetry of mourning [...with] an extraordinary diversity and range, incorporating more anger and scepticism, more conflict and anxiety than ever before" (1). Ramazani describes the changes undergone by elegy as "psycho-poetic", pertaining to both the psychological understanding of mourning and to generic conventions (xi). The traditional elegy, as discussed by Peter Sacks, is driven by a "compensatory" logic which allows the poet to "redr[ess] loss and overcom[e] grief by installing a substitute for the lost person" through the poem (in Ramazani 1994: xi). In contrast, the modern elegy, Ramazani argues, is "melancholic [...] the modern elegist tends not to achieve but to resist consolation, not to override but to sustain anger, not to heal but to reopen the wounds of loss" (xi). This shift away from what Ramazani calls "normative" mourning leads to a loosening of generic constraints and tropes, particularly those with a consolatory or redemptive purpose such as the "pathetic fallacy", whereby nature is personified as a sympathetic mourner (72), or "the transfiguration of the dead into [...] heavenly things" (7), an example of which was seen earlier in D'Aguiar's poem.

The reasons for the psycho-poetic evolution of elegy are partly to be found in the socio-historical changes of the twentieth century. If, as Eliot explains in his essay on literary tradition, "the material of art is never quite the same" (1975: 39), in the modern world elegists have been confronted with "industrialized warfare", the increase in "mass death", or the debilitation of "mourning rites" (Ramazani 1994: 1 ), all of which calls for more "credible responses to loss" (361). Another elegy scholar, Clifton Spargo, claims that our responsiveness to death, particularly to those deaths which are perceived as "unjust" due to their unnaturalness and preventability, also needs to be ethical, and it is the melancholic elegy that opens up a space for ethical mourning to take place (2004: 21). "Melancholia" is, for Spargo, "the elegy's most persistent sign of a dissent for conventional meanings and its similarly persistent sign of a dedication to the time and realm of the other" 
(11). In contrast to the psychoanalytical approach, where a prolonged attachment to the lost object — "beyond a certain culturally determined time frame" - is deemed pathological and impractical, Spargo cautions about the risks of what this model prescribes as "healthy" or "successful" mourning: "How are we to know when the acceptance of death, which necessarily means relinquishing the other to death, might also mean tolerating unjust deaths and those who perpetrate them?" (20; also 2010: 429). The "revisionary elegist" is for Spargo the one who yields himself to this kind of poetic oppositional approach, resisting the act of "ethical abbreviation" involved in composing poetry that symbolically compensates and redeems the loss of the other, and therefore diminishes "the other's value", and signals "the end of responsibility" (2004: 133). Spargo explains that this oppositional drive results in the "anti-elegy" which, far from being a new type of poetry or a rejection of the genre as the term may suggest, entails an adaptation of this body of verse to a different milieu and the intensification of certain tensions already present in the tradition. This trend "becomes fully pronounced by the middle of the twentieth century, extending thereafter into the late twentieth and now into the early twenty-first century" (2010: 416). As my analysis will try to show, "Elegies" is closely aligned with this poetic development and D'Aguiar emerges as an epitome of Spargo's revisionary elegist in this piece.

A dominant feature of D'Aguiar's "Elegies" is the way an anti-elegiac impulse is unleashed after the more conventional Part One of the sequence, as if to free the elegist's meditation from the most constraining aspects of tradition. While the apotheosis that provides the ending for the initial part of the sequence suggests an upward-moving transfiguration of the dead in nature, subsequent poems articulate a figurative movement downwards allowing the poet to be reunited with the dead he seemed to have relinquished in order to "serve" them through "memory and imagination" (2009: 59). In fact, later on in the sequence he admits that his "lyric builds meaning in a deepening circle" (108), implying the idea of a void or absence that can be articulated but not filled. This way the author is shifting away from a culture of commemoration that often invites us to "look past (which is to say away from) the depths of loss" (Spargo 2010: 429). It is worth noting at this point that, as makers of poetic memorials, elegists are confronted with similar issues as those facing the designers of material memorials. James Young addresses this shared preoccupation as follows: "How to articulate a void without filling it in? How to formalize irreparable loss without seeming to repair it?" (2016: 3; also Ramazani 1994: 362). Artists such as Maya Lin in her Vietnam Veterans Memorial and, more recently, Jonas Dahlberg in his Memory Wound commemorating the victims of the Utøya massacre of 2011 in Norway, have met this challenge by creating 'negative forms', "carved-out pieces of landscape [inviting] the visitors' descent downward (and inward) into memory" (Young 2016: 3). Part Two of "Elegies" marks the 


\section{Elegy in and out of Bounds in Fred D'Aguiar}

beginning of a melancholic or anti-elegiac shift which finds a formal counterpart in the disappearance of the chain rhyme characteristic of Part One, as well as in the disruption of the sonnet structure, which in some poems is reduced to the fourteen-line pattern with no stanzaic divisions or the use of couplets instead of tercets. Through shocking imagery, the bereaved poet articulates his ongoing exposure and proximity to the dead. Poem three stands out from the rest in its insistent use of autorhyme - the rhyme of a word with itself - to emphasize the disturbing image of a bed made of body parts:

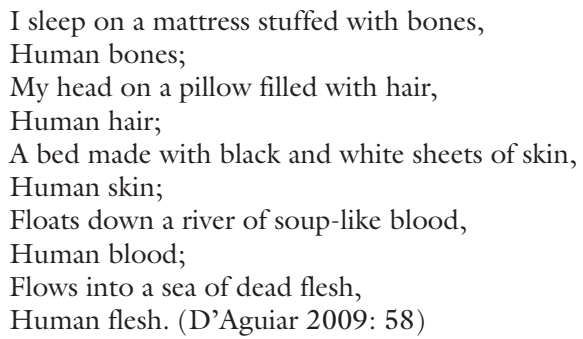

One cannot fail to notice the way these raw images of dismemberment, isolated for further emphasis in the second line of each couplet, bring echoes of extreme cases of mass death of innocents like the Holocaust, a connection that D'Aguiar has used in his engagement with other massacres (López-Ropero 2020). The idea of closeness is carried over to the next poem: "My skull carries all the dreams of all those bones./ [... I] wear their hair on my head and on my back" (D'Aguiar 2009: 58). Although these images are less crude, with perhaps the exception of the bone metonym to refer to the victims, they nonetheless convey a sense of very close proximity and even physical incorporation of the dead, as the poet now bears the hair of the victims on his own body (58). Expressions of the poet's continuing bonds with the deceased recur through the whole sequence, foreclosing any sense of resolution or end to mourning. An example may be found in Part Twelve, when the poet explains:

For I am a man on the edge of a calamity, Stuck there after the world has moved on, For I keep the company of dead children, We talk about spilled blood and dead flesh, How to live good and keep thoughts fresh. (94)

The final couplet is remarkable in the way it contains images that have appeared earlier in the sequence — spilled blood and dead flesh — with the irony underlying the idea of conversing with the dead about good living, and in the association brought about by the rhyming of "dead flesh" with "fresh", suggesting that the 
dead are still vivid in the poet's imagination and memory. This feeling is retained only to become more severe in the final section of the sequence, Part Twenty-One. Here the victims are presented as "hooks / With their names sunk in [the poet's] flesh" (D'Aguiar 2009: 118). The image of the hook brings into sharp relief the elegist's vulnerability through his exposure to the loss of the other. It is as if, to quote Jean-Michel Ganteau, "the sense of loss" had been "replaced by pure, endless relationality negating the subject's autonomy and vindicating his dependence on the lost other, hence his vulnerability" (2017: 29). At the same time, we must understand that this "susceptibility to damage and loss" is a productive one, as "it guarantees man's ethical and political orientation” (Ganteau 2017: 38). Lines like "I eat the spoor of the dead/ When I breathe, when I walk, when I run" found in the very last poem (D'Aguiar 2009: 121) show that the poet continues to be deeply invested in his responsibility to the deceased until the end of his elegy.

\section{Grief as Occasion for Critique}

The dynamic of resistance to consolation that propels this lengthy elegiac sequence creates a developing poetic perimeter within which the ethical work of mourning can take place. The sustained expression of grief may prove cathartic for the poet on a personal level, but it also favours his commitment to protest at the unjust death of the other, and his critical engagement with the causes that may have contributed to the terrible event. As Erika Doss argues in her study of the memorialization of the Columbine High School killings and other extreme events, "a superficial engagement with psychic closure — on healing and surviving — skirts the causal historical dimension of these visibly public deaths", which she relates to an extant "culture of violence in America" (2002: 71). If death is considered particularly unjust and untimely when the victims are young individuals, the fact that the killings took place in a higher education institution, the victims' gateway to the future, adds more poignancy to their demise. Besides, if the loss of young lives has traditionally elicited a particularly mournful elegiac response, given its marked unnaturalness and implications of "failure" and "lost potential" (Ramazani 1994: 256), the high death toll of school shootings, the Virginia Tech case being the most lethal to date, makes this event particularly painful. D'Aguiar highlights this unfairness in mournful lines like "roads that lead, not to long lives, but early burials" (2009: 61), often showing his empathy as a father — "If you bury a child the rest of your life/Spoils even though you live it as best/As you can" (113). In a more lyrical passage, the poet uses a butterfly metaphor to articulate the different elements he associates with the campus dead; namely, promise, vulnerability, parental hope, and trust betrayed by unsafety: 
At this moment I am all memory, freighted by Names and faces picked out from a crowd Randomly. They were transported here At fridge temperature and released in the open: Brush-tailed butterflies dropped on campus For safe keeping [...]

[...] That's how the young

Seem to me, from my middle-aged bunker:

Delicate as butterflies, with a butterfly's agility;

Ready to alight on any surface that holds promise.

All their camouflage colours could not save them,

Nor my wish to shield them from the gun's flame. (63)

The image of the butterfly released in the open to thrive reverberates with connotations of a bucolic campus landscape of innocence and natural growth. And yet, as Spargo explains, with "unnatural deaths $[\ldots]$ such visions of pastoral harmony", so typical of classic elegies, can only be "artificially or ironically conceived" (2004: 233). D'Aguiar does not use irony but chooses to curtail the pastoral potential of his imagery by introducing a somewhat abrupt anti-elegiac turn in the final couplet of the poem. Here, the vulnerability of the young is evoked by the image of the burnt butterfly, and society's failure to protect them is emphasized through internal rhyme ("save" / fllame") and pararhyme ("them"/"flame").

The opening lines of the previous poem — "I am all memory, freighted by/ Names and faces picked out from a crowd/ Randomly"- declare the poet's responsibility to remember the arbitrary death of others. His complaint therefore becomes an occasion for effecting social critique and, in line with Doss's argument, he looks into the systemic dimension of the catastrophe, echoing the controversy over gun regulation that inevitably resurfaces after each rampage shooting in lines like "weapons / You can buy legally before you can legally drink" (D'Aguiar 2009: 54). Furthermore, he transcends the topicality of school shootings by placing this phenomenon alongside a continuum of historical violence that includes Western expansion, racial violence, or foreign interventions. D'Aguiar traces the roots of gun culture in America back to the history of Westward expansion and conquest, as the following apostrophe shows:

Oh unbecoming nation.

Your best moment and worst

Maybe that frontier that you faced with a Smith

And Wesson over your shoulder and a holster

Stuffed with a revolver and bullets for a belt.

Was the dark bearable then? And if it was not,

You emptied your clips into it and howled. (105) 
This passage presents the use of firearms as an acquired habit of overprotection rather than a survival skill. The poet's grief becomes racially inflected as he recounts an occasion when he was passed by two white men in pickup trucks during a jogging session and feared being shot, "For a man with guns could only be read/ As one false move and you're dead" (D'Aguiar 2009: 90), throwing into relief a history of black people's vulnerability to gun violence. Another ramification of this bellicosity is the Iraq war, which leads the poet to compare human loss when it is caused elsewhere like an "export", and when it happens on the "domestic" front, where the dead are also "rising" (66). It is noteworthy that school shootings do not simply constitute manifestations of a systemic culture of violence, but are also contributing to shape this culture. As has been argued, "the school shooting script [e.g.: high death toll, random selection of victims, detailed planning, publication of photos and videos, search of notoriety] is one of the many contemporary resources for mass murder, and it has moved far beyond the realm of the school" (Sandberg et al. 2014: 281). Acts of lone-wolf terrorism such as the Utøya massacre, where sixty-nine young lives were taken, follow the pattern of notorious gun rampages like Columbine and Virginia Tech. As a disconsolate mourner, D'Aguiar invites a critical reflection on the roots and consequences of mass death in advanced societies, school shootings being one its most visible contemporary manifestations.

Another revealing example of D'Aguiar's discerning critical eye as an elegist is his engagement with the controversy surrounding the issue of how the Virginia Tech massacre should be collectively remembered and commemorated. The debate was triggered by the construction of a temporary memorial by a student organization - Hokies United - who during the night following the tragedy built a semicircle of thirty-two limestone blocs with the names of the victims and placed it on the campus main field. The perimeter of this memorial installation was soon subject to conflict, as a few days later a thirty-third stone was added by another student to commemorate the shooter, claiming that he also deserved "forgiveness and mourning" (Grider 2011: 124). This led to a situation where the new stone, branded as the 'Cho stone' - 'Cho' being a short form of the gunman's name, Seung-Hui Cho- was daily removed and mysteriously replaced for some time, "the appearance and disappearance of the stone reflect[ing] the community's struggle to come to terms with the massacre" (Grider 2011: 125). While the majority of mourners believed that the perpetrator should not be memorialized with his victims, the truth is that some visitors would place flowers and memorabilia around his stone as well, even after it was removed. And when the makeshift memorial was removed to clear the site for a permanent one and the student representatives sent the stones and memorabilia to the families, they included Cho's family as well (2011: 125). The official monument that was built a year after 


\section{Elegy in and out of Bounds in Fred D'Aguiar}

the tragedy found inspiration in the student-made memorial, but only features thirty-two stones along its crescent-shaped perimeter.

D'Aguiar does not fail to address this public mourning controversy. In keeping with the more conventional discourse of Part One explained earlier, at the elegy's onset the poet refers to "thirty-two innocents killed" (2009: 54). Yet in subsequent parts of the sequence the count shifts to a loud "thirty-two, no, thirty-three" (58, $119)$ or the disturbing "thirty-three fishhooks" (118) that continue to torment the elegist at the close of his piece. It is true that the poet chooses to postpone his reflections on the shooter and "serve" the memory of his victims first (59) and, unlike the case of the student Erin, he never refers to him by his name, but he comes to the realization that his was also an untimely death, as he reveals in the following lines:

\footnotetext{
I began and found I could not separate Him from them because he too was in His prime, and though his hand had made The cuts, he was among the slaughtered. Thus I find myself thinking about his loss And theirs as multiple sides of a prism. (73)
}

The poet's choice to mourn the shooter is consistent with the importance he attaches to the socio-historical forces at play in the massacre. In regarding Cho as another victim D'Aguiar refuses to consider the tragedy as the consequence of the aberrant behavior of a single individual, a narrative that the material memorial appears to endorse and that the media certainly embraced in their sensationalistic handling of the event. As Erika Doss points out, in certain cases if the perpetrator is "effaced from the memorial", the "act bec[omes] an isolated incident rather than part of a historical continuum of violence and terrorism" (2002: 79). The media coverage of the tragedy projected an image of the student gunman as an evil and mentally deranged individual, particularly through the airing of the photos and video that Cho had sent to NBC News, where he appeared uttering threats and wielding guns (Walsh-Childers et al. 2011: 196). D'Aguiar's position regarding the shooter deviates from this consensus, ruling out epithets like "Beelzebub" or "madman" to qualify him, for the more explanatory "manmade" (2009: 59).

D'Aguiar endows his elegy with a critical comprehensiveness which enables him to address a wide range of issues relevant to mourning in the modern world. A sense of place is not lost to the poet's penetrating vision, and he engages with the campus transformation into a site of memory after the tragedy, but does so with a critical stance regarding the efficacy and legitimacy of contemporary trends in mourning, avoiding any hint of sentimentality or solace. He describes how the campus main field has morphed into a site of death and memory: 


\section{Lourdes López-Ropero}

Cut flowers, placed around stones with names,
Wilt in the sun, but never lose their charm.
They lose their sweet scent and bees avoid
Them and seek out living gardens, not this
Mausoleum for the campus dead. (D'Aguiar 2009: 93)

This passage could be said to have anti-pastoral undertones, as any potential for beauty, peace and growth is undercut by the reference to dead flowers that the bees disregard in search of "living gardens". In another telling, albeit shocking, example we read "And only [the dead's] cell phones for bees around flowers" (D'Aguiar 2009: 71), summoning the image of victims fallen in a field of death. Reduced to the phrase "stones with names", the Hokie memorial appears to be devoid of any meaning or use. And yet the poet seems to be implying that an ambiance of absence is more suitable than one of presence - people, media, protocols - to truly confront loss and honour the memory of the departed. Such an atmosphere was particularly missed in the case of the Virginia Tech disaster, a major news event which received a great deal of commercial media attention, and turned into an epitome of "journalistic insensitivity" (Walsh-Childers et al. 2011: 195) —at some point, 130 satellite television trucks could be counted on campus (192). Thus, in another campus perambulation, the poet highlights the difficulty of experiencing the profound emotion that mourning requires in a space full of visitors, memorabilia and condolence objects: "noticeboards tell us/ What to think about our loss./ Silence and nothingness disappear/ Just when you need them, leaving us/ Burdened with throwaway greet-/ ings" (D'Aguiar 2009: 69). At other times, the poet seems to accuse the speed and exuberance of communication in the age of the image of being disrespectful with the dead, while catering to the needs of the living as avid consumers of mediated disaster, "While the dead lie in mortuaries, their names and faces shine/ Through optic fibres and satellite feeds for all time" (54). We may infer from all these poetic reflections that issues such as the offensive profanity of the media coverage of disaster, the transformation of grief into spectacle, or the superficial clatter of public mourning have become part of the contemporary elegist's dirge.

\section{Conclusions}

In his acceptance speech of the Nobel Prize for literature, John Steinbeck pronounced some words in defense of the relevance of literature, saying: "Literature is as old as speech. It grew out of human need for it, and it has not changed except to become more needed" (1962). The same argument may apply to the elegy, that ancient and revered form of poetry, in the face of the atrociousness with which 


\section{Elegy in and out of Bounds in Fred D'Aguiar}

modern death continues to confront us. Violent death not only does not spare the young. Far from it, the school shooting has become a paradigm of contemporary mass death. Four years after the Virginia Tech massacre, sixty-nine youths were killed in a summer camp on the island of Utøya by a gunman who was following the script of school shootings like the one commemorated in D'Aguiar's sequence. Unfortunately, horrific tragedies like Utøya give renewed relevance to the author's effort in "Elegies", where he seems strikingly prescient about youth vulnerability and the risks posed by firearms in the contemporary world. The refrain that runs insistently through the last but one poem of the sequence like a protest chant, "Not the sound of a gun" (D'Aguiar 2009: 120), cannot but reverberate in the readers' ears as a reminder of a lesson unlearned.

And because elegy has become even more needed in the face of the nightmares of the $21^{\text {st }}$ century, it has had to adapt to the exigencies of the present. D'Aguiar's sequence epitomizes elegy's potential for ethical protest, providing a model for the contemporary elegist to follow in his confrontation with unjust, preventable death. The traditional mold of the elegy, which allowed for the figurative rebirth or sublimation of the departed, and the consolation of the living in their progression from grief to closure, is inadequate when there is a need to extract usable lessons from the occurrence of extreme events. Contrarily, the perimeters that define this form of poetry need to be unfixed and fluid. D'Aguiar's poem suggests that for elegy to serve the troubled present it may benefit from the cultivation of an unembarrassed attachment to the deceased, from avoiding depoliticizing tragedy and from exposing its socio-historical underpinnings; in sum, it should be open to grappling with whichever issue may seem critical to the bereaved poet, be it the struggles of collective memory, or the turning of grief into mass-mediated spectacle. The maintenance of melancholic tension proves more effective for engaging in critical commentary than as a progression towards resolution.

At the close of his elegiac sequence, a sense of dual irresolution prevails both at the level of the poet, who remains disconsolate, angry and wounded, and at the level of the dead, who remain hopelessly so — "The dead cannot sing with dust/ In their windpipes and the ampoules/ Of lungs dried as bagpipes in a museum" (D'Aguiar 2009: 112). For the revisionary elegist, however, melancholia is a source of satisfaction and artistic freedom. Diana Fuss's ideas prove particularly insightful in this regard: "What, after all, could be more consoling than the knowledge that there can be no consolation? Melancholia (endless and irresolvable mourning) has become the new consolation, relieving elegists of the burden of finding and providing emotional compensation, either for themselves or for the audience" (2013: 5). For all the new freedoms and ethico-political possibilities that the melancholic turn allows contemporary elegists, D'Aguiar's deployment of 
various elegiac conventions or his resort to terza rima, especially at the onset of the sequence, as well as his sustained use of the sonnet, indicate that contemporary poets are aware of how they are contributing to shaping an extant tradition for a new century, and how tradition lends literary leverage and gravitas to the subject matter of their verse in the modern world.

\section{Works Cited}

Amano, Kyoko. 2006. “Frost's Acquainted with the Night". The Explicator 65 (1): 39-42.

BIRAT, Kathie. 2018. “'Keeping My Slave Side Well Versed': Fred D'Aguiar's Use of Ottava Rima in Bloodlines". Journal of Postcolonial Writing 54 (1): 56-68.

Burns, Jim. 2010. "Review of Continental Shelf". Ambit 199: 61.

Cannon, Calvin. 1963. “Lorca's 'Llanto por Ignacio Sánchez Mejías' and the Elegiac Tradition". Hispanic Review 31 (3): 229-238.

D'Aguiar, Fred. 2008. "Writing the Virginia Dead". The Guardian (April 16). <www. theguardian.com/books/booksblog/2008/ apr/16/writingthevirginiadead $>$. Accessed March 26, 2020.

D'Aguiar, Fred. 2009. “Elegies". In Continental Shelf. Manchester: Carcanet: 51-121.

Doss, Erika. 2002. "Death, Art and Memory in the Public Sphere: The Visual and Material Culture of Grief in Contemporary America". Mortality 7 (1): 63-82.

ELIOT, T.S. (1919) 1975. "Tradition and the IndividualTalent." In Kermode, Frank (ed.): 37-44.

ELıOT, T.S. (1923) 1975. "Ulysses, Order and Myth". In Kermode, Frank (ed.): 175-178.

Fuss, Diana. 2013. Dying Modern: A Meditation in Elegy. Durham: Duke U.P.

Ganteau, Jean-Michel. 2017. "The Powers of Vulnerability: The Restorative Uses of Elegy". In Martínez-Alfaro, María Jesús and Silvia Pellicer-Ortín (eds.) Memory Frictions in
Contemporary Literature. Basingstoke: Palgrave Macmillan: 21-40.

GrIDER, Sylvia. 2011. "Memorializing Shooters with their Victims". In Margry, Peter Jan and Cristina Sánchez-Carretero (eds.) Grassroots Memorials: The Politics of Memorialization and Traumatic Death. New York: Berghahn Books: 108-142.

Kennedy, David. 2007. Elegy. London: Routledge.

Kermode, Frank. (ed.) 1975. Selected Prose of T.S. Eliot. Harcourt: Harvest Books.

Lennard, John. 2013. The Poetry Handbook. Oxford: Oxford U.P.

LÓPEZ-ROPERO, Lourdes. 2020. “Remembering Jonestown through the Camp and the Postcolony: A Multidirectional Reading of Fred D'Aguiar's Children of Paradise". Journal of Postcolonial Writing 56 (3): 310-323.

McCulloch, Andrew. 2010. "Under the Sea". Times Literary Supplement (February 5): 22.

Norlin, George. 1911. "The Conventions of the Pastoral Elegy". The American Journal of Philology 32 (3): 294-312.

Ramazani, Jahan. 1994. Poetry of Mourning. The Modern Elegy from Hardy to Heaney. Chicago: University of Chicago Press.

RamazanI, Jahan. 2006. "Can Poetry Console a Grieving Public?" Poetry Foundation (September 12). <www.poetryfoundation.org/articles/68676/ can-poetry-console-a-grieving-public56d248486a430>. Accessed April 15, 2020. 
Robinson, Daniel. 2003. "Elegiac Sonnets: Charlotte Smith's Formal Paradoxy". Papers on Language and Literature 39 (2): 185-220.

Sandberg, Sveinung, Atte Oksanen, Lars Erik Berntzen and Tomi Kiilakoski Sandberg. 2014. "Stories in Action: The Cultural Influences of School Shootings on the Terrorist Attacks in Norway". Critical Studies in Terrorism 7 (2): 277-296.

Shelley, Percy Bysshe. 1821. "Adonais: An Elegy on the Death of John Keats". Poetry Foundation. <www.poetryfoundation.org/ poems/45112/adonais-an-elegy-on-the-deathof-john-keats>. Accessed February 26, 2020.

SPARgO, Clifton. 2004. The Ethics of Mourning. Grief and Responsibility in Elegiac Literature. Baltimore:The Johns Hopkins U.P.

Spargo, Clifton. 2010. "The Contemporary Anti-Elegy". In Weisman, Karen (ed.) The
Oxford Handbook of the Elegy. Oxford: Oxford U.P.: $414-430$.

SteINBECK, John. 1962. "John Steinbeck: Banquet Speech". The Nobel Prize. <www. nobelprize.org/prizes/literature/1962/ steinbeck/25229-john-steinbeck-banquetspeech-1962>. Accessed February 26, 2020.

Walsh-Childers, Kim, Norman P. LeWIS and Jeffrey NeELY. 2011. "Listeners, Not Leeches: What Virginia Tech Survivors Needed from Journalists". Journal of Mass Media Ethics 26 (3): 191-205.

Young, James E. 2016. Stages of Memory. Reflections on Memorial Art, Loss, and the Spaces Between. Amherst: University of Massachusetts Press.

Received: $17 / 10 / 2020$

Accepted: 12/03/2021 